\title{
The Irish Dairy Industry: Globalisation, Competition, Recession, \& Consumerism
}

\author{
Brian Clancy \\ Cork Institute of Technology, School of Business \\ Bishopstown, Cork. Republic of Ireland \\ Dr Angela Wright \\ Cork Institute of Technology, School of Business \\ Bishopstown, Cork. Republic of Ireland \\ E-mail: angela.wright@cit.ie
}

Received: February 22, 2013 Accepted: March 9, 2013

doi:10.5296/ber.v3i1.3454 URL: http://dx.doi.org/10.5296/ber.v3i1.3454

\begin{abstract}
In today's global environment, the dairy farmer and his herd have lost major importance and influence as a consequence of a variety of factors, among them the Industrial revolution, continued and increasing consumerism, the technological explosion, and the ever-expanding concentration of people in urban areas. This research study examines the Irish dairy industry in its current format. The objective of this study is to look at what dairy farmers need to do to grow and expand their business efficiently and effectively. The major challenge for the industry is to attract a new generation of knowledgeable workers to the land. This needs to be balanced by ensuring that both the deep traditions and the experienced culture of farming generations remain at the heart of agricultural practice.

The future of the Irish Dairy industry will be scrutinised over the next few years as reforms take place and economies adjust, amid the expectation that world markets will stabilise. The proposed abolition of milk quotas in 2015 will be one of the most significant landmarks in farming history since Ireland's entry into the European Union in 1973, and the introduction of milk quotas in 1984. This study also examines whether Ireland will remain on its current trend of a steady decline of individuals holding farms, and if the industry will become a gathering of "multi-nationals", similar to other commodity markets. Can the Irish dairy farming community
\end{abstract}


formalise a strategy together to ensure that all members make a substantial contribution and have an input in its future success?

After an extensive review of the relevant pertinent literature, a qualitative methodology was applied for this current research. Face to face interviews were conducted with relevant and appropriate people, including the current Irish Minister for Agriculture, Mr. Simon Coveney T.D. Nine interviews were completed for the purpose of this study, and contributors were purposely chosen because of their expertise in the area.

The study reveals that the outlook for the Irish dairy industry is a positive one, but it will be important for the industry to closely examine comparative situations, in particular to give attention to the New Zealand model. Findings suggest that dairying post 2015 can do the same for rural Ireland as it did for the South Island of New Zealand 20 years ago. Caution must also be exercised that Ireland does not experience the same social implications as the New Zealanders did. This study has found that grass-based milk production is an area where Ireland has a real, sustainable, competitive, and international advantage. The focus and ambition of the future should be for the dairy industry to turn the land of green hills and mountains into the land of the green 'notes', preferably euro notes. This study will benefit the dairy industry, farming organisations, entrepreneurs, legislators and political leaders in analysing the industry and determining its future.

Keywords: The Irish Dairy Industry, Globalisation, Consumerism, Competitive Environment, Food Production, The Family Unity, Irish Culture and Farming

\section{Introduction}

Is farming a business or a way of life? Is farm policy a question of economics or of sociology?

(Smith \& Healy, 1996: 6).

The agricultural industry has evolved from a primitive, self sustaining way of life into a global multi billion euro industry. Political, economic and social factors have shaped farming culture into the integral part of society that it is today. The aim of this research is to look at how the farming way of life has evolved from the late 1800's when it was a means for survival, into the formation of organisations which gave it a voice within Ireland, and through the last half century where the 24/7 dairy farmer now needs to be a provider, a business entity within their own field, and an educated politically savvy individual. There are new challenges emerging and growing production in other global consumer markets (New Zealand, China, Argentina, Australia, Brazil,) and they will have an effect on Irish producer's competitiveness.

Political policies post war effectively promoted and revitalised agriculture through the 1950's and 1960's. The introduction of the Common Agricultural Policy (CAP) in 1962 ensured that CAP guaranteed that farmers would be able to sell their produce at a certain price. It also was meant to increase productivity, provide a fair standard of living for farmers, stable markets, and give consumers reasonable prices. This research study will examine how CAP has influenced Ireland's dairy industry and whether it is still relevant in today's agricultural climate. Matthews (2000) relays that "farmers, once pillars of enterprise, have become as dependent on the state 
for their income as any social welfare recipient", (2000: 26). This research study examines the Irish Dairy industry in its current standing. It also examines the industries readiness for the next decade as there is expected to be a major shift in the way the business model will need to change once milk quotas are lifted in 2015. This period will also signal the end of payments and subsidies, currently called the Single Farm Payment, meaning that dairy farmers will have to rely on their own efficiencies to maintain profitability. While there may be a different form of Single Farm Payment in the future, this research study generally assumes there will not.

\section{Methodology}

The researcher posed the research question to be an empirical study of the Irish Dairy Industry, and the impact that economic, political, environmental and social factors have had on it. The research study was completed using a qualitative methodological approach, with the primary data collection method chosen being semi-structured face to face interviews. A representative sample of nine experts across a range of age, gender, with varying roles and responsibilities within the dairy industry were chosen for interview, giving a balanced, encompassing range of opinions. A flexible interview guide of 26 questions was used to conduct the interviews. The qualitative approach was more suitable for this research study as it matched the research strategy to the purpose of the study. A logical and controlled methodology was used in the compilation and analysis of the data, and the presentation of the findings. This research study examined secondary data initially from a range of journals, text books, public statistical bodies such as the Central Statistics Office (CSO), reputable internet sources, online literature databases and industry related newspapers.

\section{Literature}

\subsection{The History of Farming in Ireland}

"Cows were very important in the early Irish economy and feature in the early medieval texts. Milk cows were a unit of value. One milk cow was equal to one ounce of silver", (Kennedy, 2010: 4). "From the literary texts of the seventh and later centuries, milk and its products, especially in summer time was of the greatest importance, and milk was to keep its primacy in the national diet till the seventeenth century. It was consumed as liquid milk, curd, butter, and cheese, and all of these were prepared in a different way", (O'Cróinín, 2005: 572), then a catalyst - "the Irish Famine meant that emigration peaked earlier in Ireland than in other countries participating in the great trans-Atlantic Diaspora. The Irish outflow was so great removing one third to one-half of each rising generation, that it provoked repeated warnings of de-population ", (1989: 62). "The immediate impact of the Famine on agriculture was to obliterate over 200,000 small holdings, and drastically reduce the acreage under plough and spade", (O’Gráda, 1989: 62). "For several decades after the Famine, farming provided work for more than one half of Ireland's occupied population, and accounted for one-third or more of national output and, along with linen, the bulk of merchandise exports", (O'Gráda,1993: 55) .

Other extraneous events like the end of World War II saw further pressure on Irish farm incomes. Between 1948 and 1953, government controlled farm wages rose 40 per cent and uncontrolled fodder by 55 per cent, while fixed milk price only rose 9.5 per cent (Smith \& 
Healy, 1996). By 1967, Irish Farmers had the lowest milk prices in Europe. The West German price of 18 pence a gallon, compared to the Irish price of 10.5 pence opened no markets. Growing surpluses everywhere limited access even to the British market", (Smith \& Healy, 1996: 75). "Michael Malone, Chairman of the National Milk group, stated in 1971:"it is not often, especially in agricultural circles, when one can say that we are completely satisfied with prices", (Smith \& Healy, 1996:75). Grant (1997) adds that "further significant reform of the Common Agricultural Policy is in the interests of the EU as a political entity. It is not a good use of resources to spend over half of its budget on a policy that does not really help to sustain rural life, allows large scale fraud, increases food prices for consumers, and is environmentally damaging", (1997: 228). Rouse (2000) states that "milk prices rose from 16 pence a gallon to 64 pence in 1980 and 92 pence in 1985. Interestingly, by 2010, "the average price of milk quota traded in the quota exchange has fallen from a high of almost 30c/litre to a low of just under 8c/litre in the most recent milk quota", (Kennedy, 2010: 4).

\subsection{The Common Agricultural Policy}

According to the European Commission, "the stated aim of the Common Agricultural Policy reform of 2003 was geared towards consumers and taxpayers, while giving EU farmers the freedom to produce what the market wants", (http://ec.europa.eu). "The Common Agricultural Policy has its roots in 1950s Western Europe, whose societies had been damaged by years of war, and where agriculture had been crippled and food supplies could not be guaranteed. The emphasis of the early Common Agricultural Policy was on encouraging better agricultural productivity so that consumers had a stable supply of affordable food and ensure that the EU had a viable agricultural sector. The Common Agricultural Policy offered subsidies and systems guaranteeing high prices to farmers, providing incentives for them to produce more butter", (http://ec.europa.eu/agriculture). The Common Agricultural Policy was based on equal prices in all markets, allowing for transport costs", (Rouse, 2000: 96).

\subsection{Common Agricultural Policy Impact on European Society}

The European Commission (2010) stated "the Common Agricultural Policy's cost should be seen in context. Unlike for other sectors, such as education, defence, transport, healthcare or social security, whose cost is borne by national governments, the Member States have agreed that decisions about the EU's agricultural policy be taken at community level, and that an appropriate budget be put in place to do this. On average each citizen contributes around 2 Euros a week to finance the Common Agricultural Policy, (http://ec.europa.eu).

\subsection{Inequalities in the Common Agricultural Policy Payments}

According to the Heritages Council (1999), "the intensive dairy, pigs and poultry sectors are not 'payments driven' unlike the beef, arable and sheep sectors. Larger, more intensive dairy farmers tend to respond to prices and quotas, while the pigs and poultry sectors are de-regulated. The concentration and intensification of these industries as a response to market forces and EU milk policy gives an indication of the direction in which other farm sectors could take unless definite policy measures are introduced to counteract this tendency", (1999: 178). Matthews (2000) agrees that as a consequence of the Common Agricultural Policy and direct 
payments, "income from farming is unequally distributed. In 1992, support was provided through market intervention, 63 per cent of farm income accrued to the top 20 per cent of farms. Conversely, the 60 per cent of farms with the lowest farm incomes shared 25 per cent of aggregate income from farming", (2000: 58).

\subsection{Effect on Incomes caused by the Common Agricultural Policy}

Kinsella (2007) states that "the average Family Farm Income (FFI) on full time farms in 2006 was $€ 34,486$ compared to $€ 40,485$ in 2005 , a decrease of $15 \%$. The tillage and dairying systems had the highest FFI per farm at €50,443 and €38,690”, (2007: 37). Kelly (2007) comments that "the 2006 National Farm Survey indicates that on average, $60 \%$ of farm family income came from direct payments in 2005, on part time farms $125 \%$ of family farm incomes was accounted for by direct payments. So, a huge proportion of Irish Farmers subsidised their farming business with their Single Farm Payment, REPS payment and Compensatory Allowance payment", (2007: 9). According to Dempsey (2010), 2010 "will be the first year when Irish farm income is less than the direct payments. Clearly the main problem is the price farmers receive for their product, combined with the constraints affecting production. The collapse, especially in cereals and milk, pinpointed graphically for the first time how dependant European prices are on developments in the world market", (2010: 6).

\subsection{The Impact on Farming due to Education Levels}

The Heritage Council (1999) outlines that "the Early Retirement from Farming Scheme was introduced as part of the 'Accompanying Measures' in the Common Agriculture Policy reforms of 1992. The scheme provides a pension for elderly farmers to retire and provide an opportunity for young farmers to practice farming", (1999: 31). In addition, Matthews (2000) suggests that "farm incomes were low in the past because of the extensive underemployment on farms, because farmers generally had a low level of education and because farmers on average were elderly", (2000: 55). "The biggest single factor in the relative improvement in average farm incomes has been the availability of off-farm employment, not least in rural areas. As the education of younger farmers improves, the average educational level among farmers is rising, and with it average farm income", (Matthews, 2000: 55). According to the CSO (2007), "the total numbers enrolled in Teagasc further education agricultural courses has increased dramatically in the last number of years. In 2008, there were 621 students enrolled on agricultural courses, while in 2006, this number was only 298 students", (www.cso.ie). At higher education level, increasing demand for agricultural courses is demonstrated by the increase in point's requirements. One good example is the Bachelor in Agricultural Science in UCD, the points for which increased from 315 in 2007 to 375 in 2008. In fact, the "average points attained by students enrolling in this course were 415", (www.cso.ie).

\subsection{What Holds for the Future Markets?}

Mannion (1995) states that milk is the second most important livestock product, after meat, it constitutes a very important source of calories per capita in many developing countries. It provides 41.7 per cent of the calories that are derived from livestock products. This compares with only 26.4 per cent for developed countries. The significance of milk in diets worldwide 
reflects its production from a range of sources", (1995: 182).

Grant (1997) states that "without milk quotas, Europe has the capacity to increase milk production by $30 \%$. This would have a significant downward effect on milk prices and force smaller, less competitive producers out of business. In most member states, it would be a politically unacceptable move", (1997: 113). Dempsey (2009) argues that "we have a disjointed dairy industry model in Ireland, which means that sectors of the Irish Dairy Industry are not driven by what the world consumer wants. Up to recently, Ireland was sending produce into intervention rather than competing for global markets. "With intervention now limited, more produce will have to be sold on the world market", (2009: 33). How different is agriculture from other economic areas? There are a number of characteristics that make it different. The large number of comparatively small producers, the increasing concentration of processors and retailers, but most of all, the effect that over or under supply has on overall price levels. All of these, coupled with the political sensitivity of food and the effect weather patterns can have on supplies, make pricing and agricultural policy unique. Certainly, an argument can convincingly be made that it does not fit neatly into the World Trade framework", (Dempsey, 2010: 7). Also of note and concern for the industry, French (2010) warns that "for the last 25 years, the Irish herd has been contracting by over 15 per year and this is likely to continue for the next two years. Unless we get an increase of greater than $20 \%$ in the number of cows bred to dairy bulls in 2010, we are unlikely to fill our national quota again", (2010: 14).

\section{Main Findings \& Discussion}

\subsection{Irelands Membership into the European Union}

"When the Common Agricultural Policy was devised it was regarded as a major and exciting innovation in the field of agricultural policy. It should come as no surprise that the Common Agricultural Policy was a child of its time and should be seen in the context of agricultural policy in Western Europe in the1950's. The basic problems which had produced the main elements of post-war agricultural policy did not disappear or change with the advent of the Common Agricultural Policy and, as a result, the aims of the new policy and the instruments used to achieve them remained much the same", (Fennell,1997:241).

$100 \%$ of the respondents in this study were in favour of Ireland joining the European Union in 1973. 55\% of interviewees felt that at the time of joining the EU, Ireland was too dependent on Britain to take their produce, and that the common market opened many doors for Ireland. "All our exports at that time were to the British market and they had a very cheap food policy, we had to take a very poor price for our product". Interestingly this finding supports Coakley \& Gallagher (2009), who stated that "economic dependence on the United Kingdom inhibited a close involvement in the European integration process, as British governments remained aloof from Europe", (2009:410). Participants in this current research believe that opening the markets to include all of the European countries meant that Ireland was now in a better position to demand better price for their produce. "We needed to have a price for our product, without a good price for our product we are at nothing". Subsidies and payments came to Ireland in the form of the Common Agricultural Policy (CAP), and according to one participant, in 1973, Ireland "needed all the support we could get. I don't think we could have survived without 
joining the CAP”.

$100 \%$ of interviewees agreed that the CAP served a purpose at the time, and got Ireland into a competitive position within the European markets. An interesting finding shows that many of the interviewees would now like for restrictions to be lifted so that Ireland can increase production; CAP is now having a negative effect on Ireland's dairy industry and inhibiting progress. "I think it's nearly to the detriment now, it was great at the time, but it's losing its value" There is a great sense of positivity amongst the dairy farmers when the milk quota restrictions are expected to be lifted in 2015. "If the subsidies will go, it won't affect the dairy industry that much. Without the increase production capacity, some of the interviewees feel that it is holding the country back from being competitive. "We are not in a position to expand and grow our business and compete aggressively with milk coming in from particularly the Southern hemisphere, we are going to be wiped out in a very short space of time".

\subsection{Future Effects on Incomes and Expansion Plans by Lifting Quotas}

This research found that there was mixed opinion when it came to whether Ireland was actually ready to take on the potential increase in milk volumes when quotas were lifted. The market "is anticipating a 50\% increase in production over the next 10 years in Ireland, so, from 5.5 billion litres right now, you're talking around 7.5 billion litres in 10 years time".

A number of interviewees felt that the processing plants would be an issue, and they were not ready to take the increase in volume. "I do think we are not quite ready yet but we are getting there in terms of gearing up for the significant increase in the volume of milk we produce, process, add value to and export". The co-operatives themselves have assured farmers however that they will be ready for 2015. O'Keeffe (2011) notes that Dairygold "has spent $€ 60$ million on its facilities in recent years, and has sufficient capacity to cope with milk output growth up to 2015. Dairygold expects to invest a similar amount on plant enhancements over the next four years to manage the expected milk flow", (www.irishfarmersjournal.ie).

A very positive finding from the research study was that all the participating dairy farmers were committed to increasing their herd size and if possible their land base. "From the levels we are at the moment, we would be looking at probably double in its size over the next 5 years". Land will be one of the major challenges with regard to expansion according to the research. All of the farmers are committed in attempting to acquire extra land to stock increased herds. "We would be looking at maybe acquiring additional land around our milking platform to increase the dairy output from that perspective".

\subsection{Impacts of Economic Forces on the Dairy Industry}

(A)The Celtic Tiger

The last two decades have been a turbulent time for the Irish economy, firstly with the rise of "The Celtic Tiger" from 1995 to 2007 which was principally driven by a property boom. Dorgan (2006) notes that "A second element of the new government's action plan was moderate wage increases in return for modest reductions in direct income taxes, in effect allowing take-home pay to increase more than the pay raise granted by employers. This 
three-year Program for National Recovery involved government itself, employers, unions, and farmers. This helped to break the spiral of inflationary wage increases and ensured industrial peace", (http://www.heritage.org).

The research found that the Celtic Tiger did not have a major direct impact on the dairy farmer's profitability. "If you were a part time dairy farmer, yes it did, but if you were full time no, because as we are full time, getting a relatively inexpensive job done was next to impossible". This research study shows that the dairy industry did however receive some intrinsic benefits from the Celtic Tiger, and four respondents acknowledged that the dairy industry benefitted from the additional disposable income that was available to people during that time. One contributor notes that "consumers were buying higher value foods, so I think a lot of new foods like cheeses and yogurts and other kind of high value dairy products are selling an awful lot more now than they would have been pre Celtic tiger".

An interesting finding is that there was a feeling amongst interviewees that the Celtic tiger stripped the industry of the younger generation who went away from the farming lifestyle to seek opportunities elsewhere. "The main reason I would say it harmed it, it has diverted young people out of dairying in a major way in the last 10 to 15 years". There was an overall opinion within this research that the Celtic Tiger did not have the same devastating effect on the dairy industry as it did on other sectors, such as construction or banking. "The advantage I think of being a dairy farmer is that there is a consistency of price regardless of what the economy is doing, so there isn't the big highs during boom times but there certainly isn't the lows during recession".

\section{(B)The Current Economic Climate}

The dairy industry did not see majorly significant benefits from the Celtic Tiger, and equally all nine of the interviewees felt that the current recession and ongoing deal between the government and the International Monetary Fund would have little impact on the dairy industry. With the abolishment of milk quotas in 2015 , interviewees felt that the dairy industry was now going to be one of the driving forces for progressing Ireland forward. "It's put the focus firmly back on agriculture as being one of our indigenous industries". There was an acknowledgement among $50 \%$ of the interviewees that attaining finance to fund expansion would not be as difficult for their sector as it would be for other industries. "One of the few business areas that banks want to actually to do deals with at the moment are dairy farmers because they see it as a growth industry".

\subsection{The Role of Governments in the Dairy Industry}

The study found that the dairy farmer would like to see intervention and have the government show some leeway with regard to opening up avenues to providing some tax incentives. "I don't think the farmer can be treated the same as the ordinary person, he has to invest and reinvest if he wants to stay in the game". This research found that there were measures in place for farmers who want to lease land to other enterprises without incurring tax penalties "So if you lease land out, you're effectively not paying tax on that, that's a big incentive".

This research also showed that there was consensus across all the interviewees, who were of 
varying ages, that Government and industry must be more focussed in ensuring that the elderly farmer was given all the necessary assistance should they decide to retire. All the interviewees followed on to say that the future of the dairy industry lay with the more dynamic younger generation. Ideas put forward by the interviewees included "clarifying the rules, reducing restrictions, incentivising the older age bracket, get the non production oriented businesses to step to the side, not to disadvantage them, but to incentivise them in terms of freeing up land". One interviewee was more blunt in his observation with regard to governmental input into the dairy industry "Stay out of it, leave it alone". It was also found that the government should act more as a facilitator between Ireland's dairy industry and the European Community, with the dairy industry outlining their requirements through government. "I would see their role in more of a communicational sense".

\subsection{Grants and Subsidies}

Participating dairy farmers were asked what percentage of their incomes was made up of grants and subsidies. $75 \%$ of respondents received payments that were under $25 \%$ of their overall income, "As a dairy farmer, probably $25 \%$ ". This research found that the grants and subsidies that were introduced by the European Community through the Common Agricultural Policy, were now reaching the end of their original intended use according to the participants. "I think it's nearly to the detriment now, it was great at the time, but it's losing its value". $30 \%$ of respondents were of the opinion that any monies received by the larger farmers was justified as they had taken risks to build up their herds and their land base, and worked hard to improve their efficiencies. "I would like to see payments continuing to go to the most active farmers who are looking to produce more food, who are looking to expand their businesses". $100 \%$ of the participating dairy farmers felt that they could survive without payments, and they would not suffer a loss of income if the quotas were lifted. One farmer felt that eliminating payments would dis-incentivise some farmers to keep onto their land, therefore, presenting an opportunity to progressive farmers. "Even though I am a beneficiary from them because, I know there is loads of land around me at home that I could make a great job out of, but I will never get at the moment, because payments are maintaining those lands in non production of others".

\subsection{New Zealand - Impact on the Worlds Dairy Industry}

$100 \%$ of all respondents in this study referenced New Zealand throughout the interview process. Ireland needs to follow, but also learn from the New Zealand model. In 1984, due to the country's financial state, the government was forced to cut all payments and subsidies to farmers. The dairy industry in NZ recovered however, and utilised their natural resources to increase output. "They have an Irish rainfall with a Portuguese/Spanish temperature; with that kind of situation you can grow grass". The size of the country was also gave New Zealand an advantage over other countries in milk production. "They had the same population as Ireland in 3.5 million, but they had the same land base as the UK". 50\% of the interviewees noted that while New Zealand were able to produce large volumes of milk efficiently, they also acknowledged that over two decades, this way of life had a major social impact on the farmers of New Zealand. There were financial implications due to expansion. "There are a lot of 
farmers in NZ that are way over borrowed who are under huge pressure". There were also major social implications. "there's plenty of New Zealanders will say, not just farmers, as an industry they acknowledged that there are serious increases in suicides, there was major social costs to the policy was done in New Zealand". The competitive nature of the dairy business also meant that it could not be treated as a long term career. "We have a lot of very poor farmers in NZ and their longevity in agriculture is very short". This research found that due to this competitive nature, there was no value or sentiment within the industry. "They run their farms like businesses, if they can't pay for a farm, they give it the bank, and then next fellow moves in, it's just a business". $33 \%$ of interviewees raised this as a major concern, and believed that while they acknowledged that New Zealand was the benchmark in milk production, Ireland should learn from the mistakes made in New Zealand and ensure they did not impact on the traditional values that Irelands farming sector has. "They have no family life, the financial element of life is quite strained and what we have in this country is very valuable in our family farming unit". Ireland's Minister for Agriculture agrees with this finding, noting that Ireland can match New Zealand in production methods. "I think now we have an opportunity to do that but to learn from the lessons of NZ in terms of the mistakes that were made".

\subsection{Importance and Degree of Education that Exists Within the Farming Community in Ireland}

$100 \%$ of interviewees recognised that there was a requirement for business skills in running a farming enterprise today. $100 \%$ of the respondents also agreed that there was a level of business acumen present within the industry, but they felt it was primarily with the younger generations. "Younger farmers are I would say, but the 55/60 year old farmers are not". There was also a concern that older farmers were not able to adapt to technologies in a way that the younger generation were. "There is no fear of the younger generation, a touch of a computer and they can get anything they want". Within the research study, it was also found that there was only a minority of dairy farmers were submitting complete business accounts. The research notes that this is something that the Minister of Agriculture is looking to address with farmers. "They are not good business people in terms of managing their accounts, managing their taxes, seeking out business opportunities from what they are doing and marketing their produce. I think this is something we need to up skill our farming community and we need to partner with the private sector in doing it". Interestingly, while that research study noted that $100 \%$ acknowledged that education was a requirement, $33 \%$ of interviewees pointed out that farmers are able to contribute to profitability by managing on farm activities that require no academic experience. "That's all technical efficiencies, very much based on how good you are converting grass plant to milk, it's as simple as that".

\subsection{The Challenges Facing Dairy Farming in the Future}

There were a number of findings based on interviewee's opinions with regard to the challenges facing the dairy industry in the future. These findings were evenly distributed amongst the respondents. $25 \%$ of respondents noted that in the short term, the lack of milk quotas was identified as a major stumbling block for farmers to expand their herd sizes. "A big challenge is quota management in the short term". Another interesting finding in relation to milk quotas is that one respondent felt that the milk quota system which is currently in place has been a major 
inhibitor to farmers, as it gave them no opportunity to develop and grow their business. "Quota really removed the skills on dairy farms to plan a business and business growth over time". $25 \%$ of respondents highlighted the lack of available land as an obstacle for expansion when milk quotas are lifted. As indicated previously, $100 \%$ of the participating farmers were committed to increasing output on lifting of quotas in 2015, however, it was identified that additional land would be required for increased herd sizes. In the current economic climate, $25 \%$ of interviewees identified finance as a challenge for the future. This is a worrying finding for the dairy farmers interviewed, as it prevents them from being able to purchase land and/or cows. "I think land and getting capital to buy land will be the major stumbling blocks for a lot of farmers". $25 \%$ of interviewees stated that a shortage of skilled labour would be a challenge, albeit a short term one. "At the moment there is a lack of skilled labour force, but that is being addressed, there are extra places in agricultural college".

\subsection{The Future of the Small Dairy Farmer and the Elderly Farmer}

A small farmer was defined by the participants as one who was milking 70 cows or less. "The minimum one needs from now on is 70,000 gallons of milk output. This would equate to 60 cows". The researcher found that there was little sentiment towards the small farmer, $30 \%$ of interviewees felt that for the small farmer to progress in the industry once milk quotas are lifted, the farmers needed to expand, and those that don't, will be left behind. "What is small? I would say you would want to be in excess of 80 to 100 cows, anything under that you would probably be in trouble. I wouldn't see any future for the farmer with 30/40 cows". In contrast to the previous finding, $20 \%$ of respondents maintained that both the small farmer and dairy farmer could carry on working, it was down to how they ran their farms efficiently that will keep them in profitability. "Small dairy farmers are just smaller versions of big dairy farmers, you can still be efficient".

$25 \%$ of respondents stated that the government could do more to help the elderly farmer continue. The regulations, legislation and paperwork involved in today's farming were regarded as a big obstacle by one individual in ensuring they carried on. "I would find it very difficult to keep up with the paperwork. The fact that I was in that category, and my son was coming along, it relieved me of the responsibility". A finding of note from one individual, who commented that whether a farmer fell into the small or elderly category, they were in advantageous position when milk quotas are abolished. "The future isn't that bad because the farmer is obviously sitting on assets in terms of land, a lot of liquid assets in terms of cows, and there is a value on milk quota".

An interesting finding was put forward by $45 \%$ of interviewees was the idea of a partnership scheme where an elderly farmer would form a partnership with a younger person who would carry out the labour on the farm for a share of the profits. "Bring in some kind of a scheme in terms of legislative framework where an older farmer could allow young person in to share the revenues from a dairy farm, let them work hard that the older guy stand back, and let them share the benefits of the farm". There was also another slant on this arrangement suggested where groups of smaller farmers could get together and share resources. "I would like to see smaller farmers coming together, and maybe forming partnership companies whereby 
everybody chips in potentially leasing agricultural equipment, buying fertilisers together, collectively bringing out the vet so you don't get vet visiting charges each time individual farmer".

\subsection{The Future of Dairy Farming: 5 to 10 years}

$100 \%$ of interviewees were extremely positive about the future of the dairy industry post 2015. All predicted varying degrees of increase in milk production. The Minister for Agriculture predicts that by " 2016 volumes of milk will be up about $10 / 15 \%$, in 10 years time. I would see volumes of milk up about 50\% in terms of output". Over the next 10 years, $30 \%$ of respondents calculated that there would be a reduction in the overall number of farmers in Ireland as production units got bigger. "You will see more people getting back into cows, land being leased, people are going to get bigger and bigger, and the age structure will take out certain people". In the longer term, one interviewee sees a reduction of almost $50 \%$ in the number of dairy farmers. "I can see the number of dairy farmers falling from 18,000 probably to somewhere around 8,000-10,000 over a space of certainly 10 years".

A finding of note is in relation to the price of milk, and the respondent states that over supply of milk post 2015 will possibly result in a drop in price. While this is an economic factor of the laws of supply and demand, the Minister for Agriculture agrees with the previous interviewee that there is abundant market share for countries to supply into. "Infant formula markets in China are huge markets that are growing at an extraordinary rate, at about $20 \%$ per year and that's the market we just can't fill by ourselves". The industry needs to exercise caution in anticipation of the large expected increases in production, and refers to a previous finding that the family farm is still an integral part of Irish society. "I think they should hasten slowly, the strength of the dairying industry is that it is family farm based and if they could keep it that way, keep the family farm and develop them up to their full potential".

\subsection{Marketing Ireland's Dairy Industry in the Future}

The dominant finding in this research was once again around partnerships, this time amongst the co-operatives and food bodies. 55\% of respondents would like to see some form of partnership formed, whether it is in the form of collaboration, joint ventures, sharing of knowledge and resources. Respondents felt that the sales channels were too fragmented. "You've got co-operatives/PLC's individually selling product as well, and it seems that we are competing with ourselves on international markets as suppliers to big companies". $20 \%$ of respondents identified the Asian countries, in particular China, as high potential markets for quality Irish milk products. They commented on China's increasing middle class, and the prospective increase in demand for protein products. "Tell the good news story that is Irish food in terms of safety, consistency and the brand of the promise that comes with Irish food, a lot of middle class people in other parts of the world want on their supermarkets shelves". $20 \%$ of respondents also identified the large multi-national New Zealand Company Fonterra as a marketing model that Ireland could mould their strategy on. According to Fonterra they "are one of the lowest costs, sustainable dairy co-operatives in the world. We have become the world's largest dairy exporter with nearly 11,000 shareholders. We export 95 per cent of our New Zealand-made dairy products to our customers and consumers in more than 140 countries. 
Our milk tankers collect around 14 billion litres of milk every year", (www.fonterra.com).

One interviewee comments that Fonterra is a global manufacturing and marketing machine. "It looks like they will be taking milk from Europe to sell it to Asians because of their power and co-ordination in terms of marketing". This finding was backed up by another interviewee who commented that Ireland's organisations are too busy competing with each other. "At the moment it is very disorientated, all different co-ops and milk processors are selling their products individually abroad and in some cases competing with one another whereas they should come together to do all of that". Goldstein (2004) describes Ireland as "a small island, west of England, covered with rolling hills, rocky fields, and sparkling lakes. Lush and green, it is nicknamed the Emerald Isle", (2004:6). Interestingly, 30\% of respondents commented on this worldwide recognition of Ireland as a green nation. Whilst this may be perceived as a fantastical notion, one interviewee thinks it could work for Asian markets. "If you put up a picture of green mountains and fields, cows in front of it, the market will lap it up in China or Japan, and Europe even. A lot of the European cows are reared inside the whole year, we have a beautiful countryside". A more relevant slant on the 'green' Irish theme is where two interviewees identify Ireland's grasslands as our major competitive advantage. "Most of the milk is produced from grass; it is a very green food, a clean food". Another finding from this research study highlights the opportunities that are available to Irish dairy farmers in producing milk off what is essentially a cheap product to grow. "I also think we don't value the quality of our products, the nutritional benefits of product produced from grass, in a very healthy and clean manner. Only about $10 \%$ of the world milk is produced from grass, it's a natural clean for milk production".

\section{Recommendations}

The following recommendations emerged from the empirical data gathered:

- Financial Planning - Dairy farmers have little or no influence to input costs on their farms, e.g., fuel, food concentrates, fertilisers. Access to finance in the current climate is extremely difficult. Therefore control on expenditure and maximising income is imperative for dairy farmers. This current research shows that there are less than $10 \%$ of dairy farmers actively preparing budgets, cash flows and financial accounts. The general practise outside of this is to present income and expenditure receipts to their personal accountants. It is recommended that government put in place a five year plan making it a mandatory requirement that dairy farmers are up-skilled and educated in basic computer skills, basic accounting practises and budgetary management.

- Grassland Management - This current research identifies grass as one of the major contributors towards the profitability of dairy farmers. It is a natural product, and relatively cheap to produce in comparison to the cost of producing grass silage, hay or purchasing food concentrates. The researcher recommends that government, farm bodies, and other organisations along with research institutes engage in an aggressive promotional campaign in order to educate the entire dairy farming population and not just the top $20 \%$ in grassland management techniques. This could ensure that the full acreage of every farm will be at its 
full potential, ensure higher volume and quality of milk produced. It would also contribute to decreasing the overall expenditure on farms.

- The researcher recommends that incentives are provided for small and elderly farmers to be providers of high quality replacement heifers. This will relieve the need for larger practising dairy farmers to hold stocks that add no short term value add to their farms. It is recommended that this should be implemented over the next 12 months as the current dairy cow will subsequently be calving in 2013. This would mean that for 2015 those females would be calving down post 2015, so, forward planning is essential in this area. It would also benefit both small and the elderly sectors of farmer as it would be less labour intensive than current 7 day milking practises.

- Liaison between farmers and processors to bring them closer together. The dairy farmers need to be able to project their expected volumes over the next 5 years and in particular, for the first two years post 2015. The processors need to review capacity and expand to meet the growing demand. Government can be the intermediary in this process, as costs to be incurred by the processing plants is still unknown as to who will pay for these, i.e., farmers, co-operatives, consumers.

- This current research recommends the promotion of the Farm Partnership Agreement and the Milk Production Partnership scheme. While it is currently in place, as the industry reaches lifting of milk quotas in 2015, there will be increased demand for land, dairy stock and facilities. Under this scheme, it will encourage the more efficient use of underutilised land and facilities, and will organically improve and grow same. The industry would also see social benefits, reduction in hired labour, improved 'skill set', and better management decision making.

- The study proposes an increase in current tax exemptions on the leasing of land whereby landowners who lease out their land for a period of 10 years or more qualify for an income tax exemption of $€ 20,000$ per year. In the case of leases of $5-7$ years the annual tax exemption is $€ 12,000$, and for $7-10$ year leases the annual tax exemption is $€ 15,000$. The study recommends:

1. A reduction in the amount of years required to lease the land, particularly in the case of an elderly farmer (e.g., from 5-7 years down to 3-5years).

2. Increased tax relief for longer term leases, (e.g., > 10years).

\section{Conclusions}

The future of the Irish dairy industry looks extremely positive. To use the words of one the interviewees, "it could be our next Celtic Tiger". If the projected plans of Ireland's farming community do come to fruition as indicated in this study, then they also need to look back at what happened with the New Zealand model over the last 20 years. The New Zealanders model has been an enormous success story but it has also has an overshadowed by the destruction of the family farm unit, in some case resulting in financial ruin, major reduction in the number of production units, and unfortunately a trend of suicides. Irelands farming foundations have been 
built around the family unit, and while succession farming has been somewhat in decline due to employment outside of farming over the last decade, there is now an opportunity once more to build on the industry as a more educated, computer literate generation enters the frame. Lessons need to be learned from:

1. The negative aspects of what happened in New Zealand.

2. What happened financially over the last 15-20 years in Ireland, particularly, the construction industry boom and subsequent derailment with devastating job losses.

Like many industries, a top $20 \%$ of producers will be the benchmark of the industry. These will be the farmers who will produce the greatest volume and highest quality milk. Government and industry however, must not forget about the other $80 \%$, who are either geographically or scale disadvantaged, or, who simply want to make a comfortable living from their farms. These farmers are pivotal in ensuring that the industry continues to flourish and are an integral part of the overall scheme. Regardless of the volumes produced, the industry has the ability to process it and provide an outlet for it. Infant formula, growing Asian markets and demand for high quality milk derived products abroad can be a provider of employment for the second half of this decade and beyond. The future success the Irish dairy industry is not just important for the sector itself, but for the whole country. "Farmers argue - what is good for farming is good for the whole economy", (Mattews, 2000: 68).

\section{References}

Coakley, J., \& Gallagher, M. (2009). Politics in the Republic of Ireland, $5^{\text {th }}$ Edition , Oxford: Taylor \& Francis.

Crotty, R. (1990). Farming Collapse: National Opportunity, Leinster Leader, Naas.

Dempsey, M. (2009). The Asset that is the IDB, Irish Farmers Journal, $26^{\text {th }}$ December p.33.

Dempsey, M. (2010). Lessons from the last 6 months: Irish Farm Incomes at $67.9 \%$ of 2005 levels, Irish Farmers Journal, 2nd January pp.6-7.

Fennell, R. (1997). The common agricultural policy: continuity and change, Oxford:University Press, England.

French, P. (2010). Expansion in Dairying, Today's Farm, Jan/Feb, 21(1), p.29.

Gardner, B. (1981). The Governing of Agriculture, Kansan: University Press of Kansas.

Goldstein, M. (2004). Irish in America, Minneapolis:Lerner Publications.

Grant, W. (1997). The Common Agricultural Policy, Mac Millan Press Ltd., London. http://dx.doi.org/10.1038/37213

The Heritage Council. (1999). Impact of Agriculture Schemes and Payments on Aspects of Irelands'Heritage, Dublin: The Heritage Council of Ireland, Dublin.

Kennedy, J. (2010). Almost $€ 70,000$ wiped off value of milk quota for farmers with 65 cows, Irish Farmers Journal, $9^{\text {th }}$ January, p.4. 


\section{Macrothink}

Business and Economic Research ISSN 2162-4860

Kelly, Dr. T. ( 2007). Monitor the Profit or it will sink you, Today's Farm, Jan/Feb, 18(1), 9.

Kinsella, A. (2007). Farm Incomes: Why averaging conceals the bigger picture, Today's Farm, Sept/Oct, 18(5), 37.

Matthews, A. (2000). Farm Incomes, Myths and Reality, Cork: Cork University Press.

Mannion, A.M. (1995). Agriculture and Environmental Change: Temporal and Spatial Dimensions, Dublin: John Wiley and Sons.

O’Cróinín, D. (2005). A New History of Ireland: Prehistoric and early Ireland, Oxford:Oxford University Press.

O'Gráda, C. (1989). The Great Irish famine, Economic History Society, Cambridge:Cambridge University Press.

O'Gráda, C. (1993). Ireland before and after the famine: explorations in economic history, 1800-1925, Manchester: Manchester University Press ND.

Rouse, P. (2000). Ireland's Own Soil - Government and Agriculture in Ireland, 1946 to 1965, Irish Farmers Journal, Dublin.

Smith, L. \& Healy, S. (1996). Farm Organisations in Ireland. A Century of Progress, Dublin: Four Courts Press, Dublin.

Internet Web References

http://www.idb.ie/section/HistoryofDairyinginIreland

Retrieved $10^{\text {th }}$ June2011 9:15pm

http://www.farmersjournal.ie/site/farming.php?newsid=13318

Retrieved $11^{\text {th }}$ Sept 2011 00:18

http://www.farmersjournal.ie/site/farming-Dairygold-outline-processing-plans-13318.html

Retrieved 11 ${ }^{\text {th }}$ Sept 2011 00:05

http://www.heritage.org/research/reports/2006/06/how-ireland-became-the-celtic-tiger

http://www.heritage.org

http://ec.europa.eu/agriculture/mtr/sum_en.pdf -

Retrieved 10 $0^{\text {th }}$ June 2011 9:55pm

http://ec.europa.eu/agriculture/capexplained/change/index_en.htm

Retrieved 10 ${ }^{\text {th }}$ June 2011 9:40pm

http://www.cso.ie/releasespublications/documents/agriculture/current/livestock.pdf

Retrieved $3^{\text {rd }}$ November 2009 11:10pm 


\section{Macrothink}

www.fonterra.com

Retrieved $11^{\text {th }}$ Sept 2011 11:05pm.

\section{Copyright Disclaimer}

Copyright reserved by the author(s).

This article is an open-access article distributed under the terms and conditions of the Creative Commons Attribution license (http://creativecommons.org/licenses/by/3.0/). 